Nig. J. Biotech. Vol. 33 (2017) 97-105

ISSN: 01891731

Available online at

http://www.ajol.info/index.php/njb/index

and www.biotechsocietynigeria.org

DOI: https://dx.doi.org/10.4314/v33i1.14

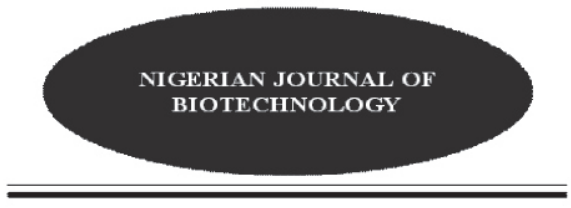

\title{
Enhancing the biodegradation process of cassava (Manihot esculenta Crantz) peels in dump site
}

\author{
Aisien, E. T. ${ }^{1}$ and Ikenebomhe, M. J. ${ }^{2}$
}

${ }^{1}$ Department of Environmental Management and Toxicology, University of Benin, Benin City,

Nigeria. ${ }^{2}$ Department of Microbiology, University of Benin, Benin City, Nigeria.

(Received: 09:06:2017; Accepted:15:08:2017)

See http://creativecommons.org/licenses/by/4.0/

Condition of use: The user may copy, distribute, transmit and adapt the work, but must recognize the authors and the Nigerian Journal of Biotechnology

\begin{abstract}
Cassava (Manihot esculenta Crantz) peels have been implicated in serious environmental pollution. This study was aimed at investigating the effect of N.P.K (15:15:15) and microbial inoculants on the biodegradation process of cassava peels. Fresh cassava peels were subjected to biodegradation process for twenty weeks. The process was monitored by determining the moisture content, starch and total lipid using the official method of analysis of A.O.A.C, total protein by Kjeldahl method, total soluble carbohydrate by the modified Anthrone method, cellulose by the Nitric acid method, total cyanide by the modified alkaline picric acid method and pH using a Jowrey $3020 \mathrm{pH}$ meter. The results of unsupplemented cassava peels and cassava peels supplemented with inorganic fertilizer N.P.K. (15:15:15) in experimental waste dump sites in which combinations of pure microbial cultures were used to inoculate cassava peels showed that pH increased from 5.89 to 7.03 , total soluble carbohydrate concentrations decreased from $2.23 \%$ to $\mathbf{0 . 0 2} \%$, protein from $5.54 \%$ to $\mathbf{0 . 7 8} \%$, lipids from $3.00 \%$ to $0.1 \%$, starch from $9.65 \%$ to $0.02 \%$, cyanide from $0.11 \%$ to non-detectable level and cellulose from $8.80 \%$ to $0.20 \%$ at the end of the $\mathbf{2 0}$ weeks of investigation. This is an indication that the addition of inorganic fertilizer or microbial inoculants, or both enhanced the rate of biodegradation of cassava peels.
\end{abstract}

Keywords: Biodegradation, Cassava peels, Dump site, Environmental pollution, Microbial Inoculant

Correspondence: eki.aisien@uniben.edu

\section{Introduction}

Economic difficulties in Nigeria since the last three decades have resulted in the high demand for cassava products such as garri, lafun, fufu, santana and tapioca as they are cheap sources of energy. The increased demand for cassava has resulted in an increase in annual cassava peels generated over the years. It was estimated that Nigeria produced between 34 to 40 million metric tons of cassava tubers in the year 2005 and 2.96 million metric tons of cassava peels (Aro et al., 2010), while in 2006 Nigeria produced 45.7 million metric tons of cassava (Sanni et al., 2009) and 54.4 million metric tons in 2011 (Elemo, 2013). Cassava processing produce large amounts of waste and is generally considered to contribute significantly to environmental pollution (FAO, 2001). Globally, the amount of waste generated since the turn of the $20^{\text {th }}$ century has increased to the point where natural mechanisms for accomplishing their degradation are no longer efficient and therefore causing their accumulation (USEPA, 2005).

Cassava peels which are the major waste from cassava, are either dumped indiscriminately in a Landfill/waste dump or refuse dump where they remain as huge mounds. In spite of its good nutritional components which include protein, fat, carbohydrate, minerals, water and fibres (Morgan and Choct, 2016), the high level of cyanide and tannin has limited its usage (Ofuya and Obilor, 1994). Pondja et al. (2017) reported the removal of cyanide from cassava peels through fermentation and the subsequent application of the fermented cassava peels for treatment of mine water in a laboratory scale. 
The problems associated with the accumulation of cassava peels in waste dumps are pollution resulting from either the slow microbial degradation or burning of the peels or both, washing of the decomposing peels into nearby surface water and ground water and pollution resulting from diffusion of the leachates from the partially decomposing peels into ground water. In order to address these problems, this study was designed to enhance the biodegradation process of cassava peels in waste dump by introducing inorganic fertilizer N.P.K. (15:15:15) and pure cultures of cassava peeldegrading microorganisms.

\section{Materials and methods}

Collection of materials

Fresh cassava peels were collected from women peeling cassava tubers for garri processing and a waste dump in the school of supply and transport (S \& T Army Baracks) off Uselu-Lagos Road, Benin City and stale cassava peels were collected from a waste dump site at S \& T Army Barracks off UseluLagos Road, Benin City.

\section{Waste site preparation}

Four experimental waste sites, each of about 1 meter by 1.15 meters were set up. They were designated sites $A, B, C$ and $D$ and were 30 meters apart from one another in the same environment. Site A contained cassava peels and inorganic fertilizer [N.P.K. (15:15:15) (0.5\%)], site B contained cassava peels and microbial inoculates (pure cultures of bacteria and fungi isolated from stale cassava peels obtained from the waste dump site), site $\mathrm{C}$ contained cassava peels, microbial inoculants and inorganic fertilizer and site $D$ which is the control contained cassava peels only.

Cassava peels at sites A, B, C and D were exposed to the same environmental conditions. In a bi-weekly basis, samples (triplicate) were collected for physiochemical and microbiological analysis. These include total protein, $\mathrm{pH}$, moisture content, starch, total lipid, soluble carbohydrate, cellulose, total cyanide content and isolation of microorganism involved in the degradation of cassava peels.

\section{Physico-chemical parameters}

The physico-chemical parameters determined were moisture contents, starch and total lipid using the Official method of analysis of A.O.A.C (1990). Total protein was by the method of Kjeldahl as described by Bradstreet (1965), total soluble carbohydrate by the modified Anthrone method described by Clegg (1956), Cellulose by the Nitric acid method of Kurschner and Hoffner modified by Okhamefe et al. (1991), total cyanide content was determined by the modified alkaline picric acid method of Ikediobi et al. (1980) and $\mathrm{pH}$ was monitored using Jowery 3020 pH meter. All chemicals used were of analytical grade.

\section{Enumeration and isolations of microorganisms}

Total aerobic microbial count was determined on cassava peel agar medium (CPAM), which was prepared by adding $15 \mathrm{~g}$ of Agar agar (Oxoid) to $1000 \mathrm{ml}$ of cassava peel extract prepared by adding $50 \mathrm{~g}$ of ground fresh cassava peels to $1000 \mathrm{ml}$ of distilled water. This was later stirred (after 10min) and filtered through a cheese cloth to obtain a filtrate known as the cassava peels extract. The CPAM prepared was homogenized and thereafter sterilized by autoclaving at $121^{\circ} \mathrm{C}$ for $15 \mathrm{~min}$. Bacteria counts were on CPAM containing $10 \mathrm{mg}$ nystatin to inhibit growth of fungi while fungi counts were on CPAM containing $0.5 \mathrm{~g}$ chloramphenicol to inhibit bacteria growth. All plates for bacteria counts were incubated at $37 \pm 2^{\circ} \mathrm{C}$ while plates for fungal counts were incubated at room temperature $\left(28 \pm 2^{\circ} \mathrm{C}\right)$.

\section{Characterization and identification of Isolates}

The bacterial isolates were characterized and identified according to the methods outlined by Collins and Lyne (1984) and Don et al. (2005). The moulds isolates were identified by the method outlined by Barnett and Hunter (1972) and Domsch et al. (1980), while the yeast isolates were characterized by the method outlined by Rhode and Hartman (1980) and Lodder and Kreger-Van Rij (1984).

\section{Results and Discussion}

The results of the analysis of physio-chemical parameters of the cassava peels undergoing biodegradation are shown in Tables 1 to 8 . Results are mean value of three samples collected from the same site. 
Table 1: Variation of total protein in cassava peels with biodegradation time

\begin{tabular}{ccccc}
\hline $\begin{array}{c}\text { Biodegradation } \\
\text { time (weeks) }\end{array}$ & \multicolumn{4}{c}{$\begin{array}{c}\text { Total protein (\%) } \\
\text { Experimental waste site/dump }\end{array}$} \\
\cline { 2 - 5 } & $\mathbf{A}$ & $\mathbf{B}$ & $\mathbf{C}$ & $\mathbf{D}$ \\
\hline 0 & 5.54 & 5.54 & 5.54 & 5.54 \\
2 & 5.40 & 5.40 & 5.39 & 5.40 \\
4 & 8.80 & 9.70 & 10.70 & 8.90 \\
6 & 16.80 & 16.80 & 18.80 & 11.90 \\
8 & 15.20 & 15.40 & 17.60 & 11.60 \\
10 & 12.80 & 13.70 & 14.20 & 9.10 \\
12 & 10.70 & 11.40 & 12.10 & 6.70 \\
14 & 8.10 & 7.30 & 7.30 & 3.40 \\
16 & 2.90 & 2.80 & 2.80 & 1.00 \\
18 & 0.80 & 1.40 & 1.60 & 0.20 \\
20 & 0.20 & 0.40 & 0.78 & \\
\hline
\end{tabular}

Note:

$\begin{array}{lll}\mathrm{A} & = & \text { cassava peels }+ \text { inorganic fertilizer } \\ \mathrm{B} & = & \text { cassava peels }+ \text { microbial inoculants } \\ \mathrm{C} & = & \text { cassava peels }+ \text { microbial inoculants }+ \text { inorganic fertilizer } \\ \mathrm{D} & = & \text { control sample }\end{array}$

The results in Table 1 show the variation of total protein in the cassava peels with biodegradation time. Between week 0 and week 6, the total protein increased from $5.54 \%$ to $16.80 \% ; 16.80 \%, 18.80 \%$ and $11.80 \%$ for sites $A, B, C$ and $D$ respectively. However from week 6 to week 20 the total protein decreased to $0.2 \%, 0.4 \%, 0.78 \%$ and $0.2 \%$ for sites $A, B, C$ and $D$. The increase in the total protein content of the cassava peels during biodegradation could be attributed to the growth of the microorganism that were involved in the degradation processes as indicated in the result in sites A and B which are biostimulation and bioaugumentaiton processes respectively. However, in site C which contained microbial inoculants and N.P.K which also enhanced the growth of the microorganisms, there was a more appreciable increase in total protein. The control in site $D$ without microbial inoculants and N.P.K. showed a lower total protein content when compared to sites
A, B and C. This shows that although bioremediation process took place in the control but at a much slower rate. Akinyele et al. (2011) attributed this increase in total protein in cassava peels undergoing decomposition to the high number of microorganisms with the ability to secrete certain extracellular enzymes such as amylase, cellulase and linamerase involved in their metabolism. The results of this study were similar to the one obtained by Ofuya and Nwajiuba (1990). They stated that there was increase in the crude protein content of cassava peels from $5.6 \%$ to $16 \%$ after 120 hours of fermentation. The gradual decrease in the protein content of the cassava peels from week 6 could have resulted from the buildup of toxic microbial metabolites, which might have caused the death of some of the microorganisms responsible for the degradation and this was experienced in all the sites.

Table 2: Variation of pH in cassava peels with biodegradation time

\begin{tabular}{ccccc}
\hline \multirow{2}{*}{$\begin{array}{c}\text { Biodegradation } \\
\text { time (weeks) }\end{array}$} & \multicolumn{3}{c}{$\begin{array}{c}\text { pH } \\
\text { waste site/dump }\end{array}$} \\
\cline { 2 - 5 } & A & B & C & D \\
\hline 0 & 5.89 & 5.89 & 5.89 & 5.89 \\
2 & 4.95 & 5.35 & 5.42 & 5.60 \\
4 & 4.91 & 5.16 & 5.23 & 5.35 \\
6 & 4.72 & 4.82 & 4.58 & 5.05 \\
8 & 4.58 & 4.64 & 4.36 & 4.86 \\
10 & 4.51 & 4.41 & 4.61 & 4.64 \\
12 & 5.03 & 5.01 & 5.35 & 4.82 \\
14 & 5.82 & 5.95 & 6.69 & 4.99 \\
16 & 6.46 & 6.86 & 7.05 & 5.91 \\
20 & 6.66 & 7.00 & 7.10 & 6.52 \\
\hline
\end{tabular}


The variation of $\mathrm{pH}$ in cassava peels with biodegradation time are shown in Table 2 . There were gradual decline in $\mathrm{pH}$ in all the sites from week 0 to week 10 , that is from 5.89 in week 0 to $4.51,4.41$, 4.21 and 4.64 in sites A, B, C and D respectively. This can be attributed to the biodegradation activities of microorganisms that make use of the components of the cassava peels for their own growth and release organic acids as by products which led to the decrease in the $\mathrm{pH}$. Ofuya and Nwajiuba (1990) reported a drop in the $\mathrm{pH}$ from 5.6 to 4.4 after 120 hours of cassava peels fermentation.

Table 3: Variation of moisture content in cassava peels with biodegradation time

\begin{tabular}{ccccc}
\hline \multirow{2}{*}{$\begin{array}{c}\text { Biodegradation } \\
\text { time (weeks) }\end{array}$} & \multicolumn{4}{c}{$\begin{array}{c}\text { Moisture contents (\%) } \\
\text { Experimental waste site/dump }\end{array}$} \\
\cline { 2 - 5 } & $\mathbf{A}$ & $\mathbf{B}$ & $\mathbf{C}$ & $\mathbf{D}$ \\
\hline 0 & 46.50 & 46.50 & 46.50 & 46.50 \\
2 & 33.50 & 35.50 & 33.25 & 38.00 \\
4 & 27.00 & 31.00 & 26.50 & 34.00 \\
6 & 21.50 & 22.00 & 20.50 & 24.00 \\
8 & 13.50 & 14.50 & 13.50 & 16.00 \\
10 & 10.50 & 11.50 & 10.00 & 12.00 \\
12 & 9.00 & 9.50 & 8.50 & 10.50 \\
14 & 6.00 & 6.00 & 7.00 & 7.00 \\
16 & 4.20 & 4.15 & 4.50 & 5.60 \\
18 & 4.10 & 4.05 & 4.20 & 5.30 \\
20 & 3.90 & 4.00 & 4.10 & 4.80 \\
\hline
\end{tabular}

There were decreases in the moisture content of the cassava peels in all the sites $(A, B, C$ and D) from week 0 to week 20 . These decreases might have resulted from the exposure of the cassava peels to the prevailing environmental conditions such as evaporation of moisture from the cassava peels as well as the water used by the microorganism for growth thereby reducing the moisture content of the cassava peels.

Table 4: Variation of total soluble carbohydrate in cassava peels with biodegradation time

\begin{tabular}{ccccc}
\hline $\begin{array}{c}\text { Biodegradation } \\
\text { time (weeks) }\end{array}$ & \multicolumn{4}{c}{$\begin{array}{c}\text { Soluble carbohydrate (\%) } \\
\text { Experimental waste site/dump }\end{array}$} \\
\cline { 2 - 5 } & A & B & C & D \\
\hline 0 & 2.23 & 2.23 & 2.23 & 2.23 \\
2 & 1.60 & 1.65 & 1.57 & 1.70 \\
4 & 1.10 & 1.15 & 1.05 & 1.45 \\
6 & 0.70 & 0.84 & 0.65 & 1.05 \\
8 & 0.45 & 0.50 & 0.41 & 0.65 \\
10 & 0.21 & 0.29 & 0.19 & 0.46 \\
12 & 0.10 & 0.14 & 0.05 & 0.34 \\
14 & 0.09 & 0.09 & 0.04 & 0.30 \\
16 & 0.08 & 0.08 & 0.02 & 0.13 \\
18 & 0.07 & 0.07 & 0.01 & 0.11 \\
20 & 0.01 & 0.01 & 0.01 & 0.09 \\
\hline
\end{tabular}

The total soluble carbohydrate in cassava peels with biodegradation time are shown in Table 4. In site $A, B$ and $C$, the total soluble carbohydrate decreased from $2.23 \%$ to $0.01 \%$ while site $D$ decreased from $2.23 \%$ to $0.09 \%$. The decrease in total soluble carbohydrate content can be attributed to the fact that the soluble carbohydrate served as source of carbon for the growth of the microorganisms involved in the biodegradation process. The almost complete usage of soluble carbohydrate in site $A, B$ and $C$ shows that the rate of biodegradation were high in them while biodegradation was very slow in site $\mathrm{D}$. Adeleke et al. (2017) reported that the carbohydrate content of naturally fermented cassava peels decrease with increase in fermentation time while Omafuvbe et al. (2004) attributed the decrease in carbohydrate content to the conversion of Oligosaccharides to simple sugars or the utilization of the carbohydrate as source of energy by the fermenting microorganisms for growth and metabolism. 
Table 5: Variation of starch content in cassava peels with biodegradation time

\begin{tabular}{ccccc}
\hline $\begin{array}{l}\text { Biodegradation } \\
\text { time (weeks) }\end{array}$ & \multicolumn{4}{c}{$\begin{array}{c}\text { Starch contents (\%) } \\
\text { Experimental waste site/dump }\end{array}$} \\
\cline { 2 - 5 } & A & B & C & D \\
\hline 0 & 9.65 & 9.65 & 9.65 & 9.65 \\
2 & 8.50 & 8.80 & 9.05 & 9.20 \\
4 & 7.90 & 8.00 & 7.20 & 8.10 \\
6 & 6.30 & 5.40 & 5.20 & 7.70 \\
8 & 5.45 & 4.40 & 3.10 & 6.90 \\
10 & 4.10 & 3.00 & 2.10 & 6.10 \\
12 & 3.10 & 1.80 & 1.20 & 5.00 \\
14 & 2.00 & 1.10 & 0.70 & 4.30 \\
16 & 1.60 & 0.60 & 0.20 & 3.90 \\
18 & 1.30 & 0.30 & 0.10 & 3.40 \\
20 & 1.00 & 0.15 & 0.02 & 3.00 \\
\hline
\end{tabular}

The variation of starch content in cassava peels with biodegradation time are shown in Table 5. Although there were decreases in the starch content in all the sites, the decrease in site $\mathrm{C}$ was highest as it decreased from $9.65 \%$ to $0.02 \%$, this was followed by site $B$ which decreased to $0.15 \%$, site A decreased to 1.00 and site D decreased to $3.00 \%$. The decrease observed in site $\mathrm{C}$ can be attributed to the fact that the biodegradation abilities of the microorganisms in this site were enhanced by the inorganic fertilizer that was added. This was followed by site $B$, where the metabolic activities of the microorganism also led to the reduction observed. The reduction in the starch content of site $A$ was not as high as that of site $B$ or site $\mathrm{C}$ due to the fact that the inorganic fertilizer added helped to stimulate the degradation abilities of the few microorganisms in the environment that came in contact with the cassava peels and thereby use both the nutrient in the cassava peels and the inorganic fertilizer to enhance their growth. Site $D$ had the least reduction in starch content due to the fact that the biodegradation process in it was slow because it was neither enhanced by the addition of inorganic fertilizer nor the addition of pure cultures of cassava peel degrading microorganism. Similarly, Adamafio et al. (2010) reported a decrease in the starch content of cassava peels fermented for 7 days.

Table 6: Variation of total cellulose in cassava peels with biodegradation time

\begin{tabular}{ccccc}
\hline $\begin{array}{c}\text { Biodegradation } \\
\text { time (weeks) }\end{array}$ & \multicolumn{4}{c}{$\begin{array}{c}\text { Total cellulose (\%) } \\
\text { Experimental waste site/dump }\end{array}$} \\
\cline { 2 - 5 } & A & B & C & D \\
\hline 0 & 8.80 & 8.80 & 8.80 & 8.80 \\
2 & 8.30 & 8.34 & 8.22 & 8.50 \\
4 & 7.68 & 7.94 & 7.80 & 8.46 \\
6 & 4.26 & 3.90 & 3.85 & 6.18 \\
8 & 3.19 & 3.18 & 3.06 & 5.46 \\
10 & 2.76 & 2.76 & 2.52 & 4.56 \\
12 & 2.10 & 1.86 & 1.50 & 4.20 \\
14 & 2.16 & 1.74 & 1.26 & 3.54 \\
16 & 1.68 & 1.56 & 0.90 & 3.24 \\
18 & 1.14 & 0.84 & 0.60 & 2.76 \\
20 & 0.60 & 0.58 & 0.20 & 2.40 \\
\hline
\end{tabular}


The cellulose content in the cassava peels were varied with biodegradation time as shown in Table 6. There were gradual decreases in the cellulose content of all the sites, from week 0 to week 20. At the end of week 20 the least decrease was observed in site $D$ while the highest decrease was observed in site C. It is obvious that the microbial inoculants in site $\mathrm{C}$ which were enhanced by the addition of inorganic fertilizer produced cellulase enzyme which rapidly degraded the cellulose in the cassava peels. In site B, the activities of the microbial inoculants were not enhanced so the decrease in the cellulose content were not as much as that in site $\mathrm{C}$. The decrease in site $A$ was a little lower than that in site $B$ due to the few microorganisms from the environment that were enhanced by the inorganic fertilizer. The least decrease in site $D$ is as a result of slow process of natural degradation. Ofuya and Nwajiuba (1990) reported a similar decrease in the cellulose content of cassava peels during solid state fermentation.

Table 7: Variation of total lipids in cassava peels with biodegradation time

\begin{tabular}{ccccc}
\hline $\begin{array}{c}\text { Biodegradation } \\
\text { time (weeks) }\end{array}$ & \multicolumn{4}{c}{$\begin{array}{c}\text { Total Lipids (\%) } \\
\text { Experimental waste site/dump }\end{array}$} \\
\cline { 2 - 5 } & A & B & C & D \\
\hline 0 & 3.00 & 3.00 & 3.00 & 3.00 \\
2 & 3.00 & 2.90 & 2.90 & 3.00 \\
4 & 2.80 & 2.70 & 2.62 & 2.85 \\
6 & 2.20 & 2.12 & 1.78 & 2.65 \\
8 & 2.05 & 2.00 & 1.55 & 2.45 \\
10 & 2.04 & 1.94 & 1.25 & 2.35 \\
12 & 1.70 & 1.65 & 0.80 & 1.95 \\
14 & 0.94 & 0.75 & 0.55 & 1.55 \\
16 & 0.80 & 0.50 & 0.35 & 1.20 \\
18 & 0.35 & 0.20 & 0.15 & 0.88 \\
20 & 0.16 & 0.10 & 0.10 & 0.60 \\
\hline
\end{tabular}

Total lipids in the cassava peels were varied with biodegradation time as shown in Table 7. The decrease in total lipid during the study in all the sites might be due to the microorganisms (both those from the environment and inoculants cultures) ability to utilize lipids for their own growth. Adamafio et al. (2010) reported significant decreases in fat content of cassava peels fermented for 7days. The least decrease was still observed in site $D$.

Table 8: Variation of total cyanide in cassava peels with biodegradation time

\begin{tabular}{ccccc}
\hline $\begin{array}{c}\text { Biodegradation } \\
\text { time (weeks) }\end{array}$ & \multicolumn{4}{c}{$\begin{array}{c}\text { Total cyanide (\%) } \\
\text { Experimental waste site/dump }\end{array}$} \\
\cline { 2 - 5 } & A & B & C & D \\
\hline 0 & 0.110 & 0.110 & 0.110 & 0.110 \\
2 & 0.004 & 0.006 & 0.004 & 0.080 \\
4 & 0.003 & 0.004 & 0.002 & 0.065 \\
6 & 0.001 & 0.002 & 0.000 & 0.040 \\
8 & 0.001 & 0.000 & 0.000 & 0.020 \\
10 & 0.000 & 0.000 & 0.000 & 0.020 \\
12 & 0.000 & 0.000 & 0.000 & 0.010 \\
14 & 0.000 & 0.000 & 0.000 & 0.010 \\
16 & 0.000 & 0.000 & 0.000 & 0.000 \\
18 & 0.000 & 0.000 & 0.000 & 0.000 \\
20 & 0.000 & 0.000 & 0.000 & 0.000 \\
\hline
\end{tabular}


The variation in total cyanide in cassava peels with biodegradation time is shown in Table 8. Cyanide is one of the products released when the cynogenic glycoside linamarine is hydrolyzed by the enzyme linamarase. Linamarin, which is localized in the cell vacuole easily come in contact with the enzyme linamerase as a result of disruption of the cellular integrity of the cassava peels. The action of microorganisms actually accelerated the entire processes leading to the degradation of cassava peels. The results in Table 8 showed that the decrease in cyanide concentration in cassava peels in sites A, B and $C$ at the end of the fourth week were similar. The cyanide concentration in these sites were less than $0.5 \mathrm{mg} \mathrm{CN} / \mathrm{kg}$ fresh weight. However, site $\mathrm{D}$ which contained cassava peels only still had over $65 \mathrm{mg}$ $\mathrm{CN} / \mathrm{kg}$ fresh weight at the end of the fourth week. This simply shows that the addition of microbial inoculants increased the rate of contact between the enzyme linamarase and it's substrate linamarin. The addition of inorganic fertilizers further increased the activities of the microorganism involved in the degradation of cassava peels, this is why there were no more cyanide in site $\mathrm{C}$ at the end of the sixth week. Njike et al. (2014) reported that the eradication of cyanide from cassava peels is due to cyanide contact with linamarase. Similarly, Asegbeloyin et al. (2007) ascribe cyanide degradation in cassava peels to contact between the enzyme linamarase and the cyanogenic glycoside. Kandasamy et al. (2015) reported the utilization of cyanide as a nitrogen source by some bacteria.

Results obtained from the physio-chemical parameters determined for the experimental waste site showed that the addition of inorganic fertilizer N.P.K. $(15: 15: 15)$ or microbial inoculants or both enhanced the rate of biodegradation of cassava peels.

Some of the microorganisms isolated from cassava peels undergoing biodegradation in the present study have been shown to be involved in cassava peels fermentation (Adeleke et al., 2017), while other researchers showed their involvement in the processing of cassava tubers for garri production (Zvauya and Muzondo, 1995; Blanshard et al., 1994; Ray, 1995). Since the peels have been shown to contain the same components as the cassava tuber, although richer in some of the component such as protein (Aro, et al., 2010), it is not surprising that the microorganism isolated (Table 9) during the biodegradation of the peels are the same as those involved in the fermentation of cassava tubers.

Table 9: Microbial flora of cassava peels undergoing biodegradation

\begin{tabular}{|c|c|c|c|c|c|}
\hline \multirow[t]{2}{*}{ Microbial isolates } & \multicolumn{4}{|c|}{$\begin{array}{l}\text { Experimental cassava peels } \\
\text { waste dump sites }\end{array}$} & \multirow[t]{2}{*}{$\begin{array}{l}\text { S \& T } \\
\text { Waste } \\
\text { Dump }\end{array}$} \\
\hline & $A$ & $\mathrm{~B}$ & $\mathrm{C}$ & $\mathrm{D}$ & \\
\hline Leuconostoc mesenteroides & - & + & + & - & + \\
\hline Lactobacills plantarum & + & + & + & + & + \\
\hline Corynebacterium manihot & - & + & + & + & - \\
\hline Bacillus subtilis & + & + & + & - & - \\
\hline Pseudomonas aeruginosa & + & + & + & + & + \\
\hline Staphylococcus aurerus & + & + & + & + & + \\
\hline Acinetobacter calcoaceticus & - & + & + & + & - \\
\hline Citrobacter freundi & + & + & + & + & - \\
\hline Saccharmyces cerevisiae & + & + & + & + & + \\
\hline Geotrichum candidium & - & + & + & - & - \\
\hline Aspergillus niger & + & + & + & + & + \\
\hline Aspergillus flavus & + & + & + & + & + \\
\hline Aspergillus tamari & + & + & + & - & - \\
\hline Penicillium frequentans & + & + & + & + & + \\
\hline Penicillium expansum & + & + & + & + & + \\
\hline Penicillium crustaceum & - & + & + & - & - \\
\hline Trichoderma viride & - & + & + & - & - \\
\hline Fusarium oxysporum & + & + & + & + & + \\
\hline Rhizopus oryzae & + & + & + & + & + \\
\hline Mucor hiemalis & + & + & + & - & - \\
\hline
\end{tabular}

Note: $+=$ Present

$$
\text { - }=\text { Absent }
$$


Previous workers on cassava fermentation reported the isolation of Lactobacillus $\mathrm{sp}$ and Bacillus sp (Parada et al., 1996), Leuconostoc mesenteroids, Corynebacterium manihot, Pseudomonas alkaligens, Lactobacillus plantarum (Nwankwo et al., 1989) and Citrobacter freundii (Okolie and Ugochukwu, 1988). Two yeast Saccharomyces cerevisiae and Geotricuhum candidum were also isolated during this study in addition to the bacteria and moulds. Collard and Levi (1989) reported the isolation of Geotricuhum candidum and Saccharomyces sp during cassava fermentation, also Saccharomyces sp was reported by Parada et al. (1996).

The ability of the twenty microbial isolates found in this study with cassava peel degradation, to grow on cassava peels indicated their involvement in cassava peel degradation, since they can only obtain their nutrient for growth from the hydrolysis of the cassava peel components. These microorganisms enhanced the rate of degradation of the cassava peels in the experimental sites. The rate of decreases in the physio-chemical parameters analyzed for were highest in the experimental site $C$ and this was followed by site $B$ and then site $A$, the last was $D$ which contained cassava peels only. Infact at the end of the twenty weeks of analyses, the cassava peels in D still contained appreciable amount of its components which simply indicates that the process of biodegradation of unsupplemented cassava peels in the site was very slow and takes long period to degrade.

\section{Conclusion}

The results of this present study have shown that cassava peel heaps contain various microorganisms including bacteria and fungi, which utilized the constituents of the cassava peels as source of nutrients for their growth. The addition of microbial inoculants, inorganic fertilizer N.P.K. $(15: 15: 15)$ or both enhanced the rate of biodegradation of cassava peels in waste site to reduce the period in which strong offensive smell will be produced thus ameliorating environmental pollution.

\section{Acknowledgment}

We wish to acknowledge the immense contributions of Prof. F. A. Aisien, Chemical Engineering Department, University of Benin, Benin City, towards the successful completion of this research work.

\section{References}

Adamafio, N. A., Sakyiamah, M. and Tettey, J. (2010). Fermentation in cassava (Manihot esculenta Crantz) pulp juice improves nutritive value of cassava peel.
Afr. J. Biochem. Res., 4(3): 51-56.

Adeleke, B. S., Akinyele, B. J., Olaniyi, O. O. and JeffAgboola, Y. A. (2017). Effect of fermentation of cassava peels. Asian J. Plant Sci. Res., 7(1):31-38.

Akingbala, J. O., Oguntimein, G. B and Abass, A. B. (1991). Effect of Processing Methods on quality and acceptability of 'Fufu' from low Cyanide Cassava. J. Sci. Food and Agric. 57:151-154

Akinyele, B. J. Olaniyi, O.O. and Arotupin, D.J. (2011). Bioconversion of selected agricultural wastes and associated enzymes by Volvariella volvacea: An edible mushroom. Res. J. Microbio., 6:63-70.

A. O. A. C. (1990). Official Methods of analysis. Association of Official Analytical Chemists. Arlington, V. A., U. S. A. 1420pp.

Aro. S. O. (2008). Improvement in the nutritive quality of cassava and its by-product through microbial fermentation. Afri. J. Biotech. 7:4789-4797.

Aro, S. O., Aletar, V. A.,Tewe. and Agbede, J. O. (2010). Nutritional Potentials of cassava tuber wastes: A case study of a cassava starch processing factory in South-Western Nigeria. Lives. Res. Rural Dev.22(11).

Asegbeloyin, J. N. and Onyinonyi, A. E. (2007). The effect of different processing methods on the residual cyanide of garri. Parkis J. Nutri., 6:163-166.

Barnett, H. L. and Hunter, B. B. (1972). Illustrated General of Imperfect Fungi. 3rdedn. Burgress Publication Company. U. S. A. 241pp.

Blanshard, A. F. J., Dahniya, M. T., Poultere, N. H. and Taylor, A. J. (1994). Quality of Cassava Foods in Sierra Leone., J. Sc. Food Agric 64 (4): 425-432.

Bradstreet, R. B. (1965). The Kjeldah method for Organic nitrogen. Academic press 112pp.

Clegg, K. M. (1956). The Application of the Anthrone Reagent to the estimation of Starch in Cereals. J. Sci. Food and Agric. 7: 40-44.

Collard, P. and Levis, S. (1989). A two stage fermentation of cassava. Nature 183:620-621.

Collins, H. C. and Lyne, P. M. (1984). Microbiological Methods. 5th ed. Butter Worth and Co. Publishers Limited. pp448.

Domsch, K. H., Gams, W. and Traute-Heidi, A. (1980). 
Compendium of soil fungi. Academic press, New York. 1:pp1240.

Don, J. B., Noel, R. K. and James, T. S. (2005). Introductory Essays. Bergey's Manual of Systematic Bacteriology. Williams and Wilkins, 1984. George M. G., ed. 2A 2nd ed. New York: Springer p.304.

Elemo, G. N. (2003). The prospects and challenges of cassava bread and confectionaries in Nigeria. A seminar presented during the NISER research seminar series (NRSS), Ibadan Nigeria.

F. A. O. (2001). Strategic environmental assessment. An Assessment of the impact of cassava production and processing on the environment and biodiversity. Proceedings of the validation forum on the global cassava development strategy. Volume 5: FAO, Rome, pp26-28 April 2000.

Ikediobi, C. O., Onyia, G. O. C. and Eluwah, C. E. (1980). A rapid and inexpensive enzymatic assay for total cyanide in cassava (Manilot esculenta Crantz). J. Agric. And Biol. Chem. 44(12):2803-2809.

Ponja, E. A., Persson, M. and Matsinhe, (2017). The potential use of cassava peel for treatment of mine water in Mozambique. J. Environ. Prot., 8: 277 - 289.

Kandasamy, S., Dananjayan, B., Krishnamurthy, K and Benckiers, G. (2015). Aerobic cyanide degradation by bacterial isolates from cassava factory wastewater. Braz. J. Micrbiol., 46(3):659-666.

Lodder, J and Kreger-Van Rij., N. J. W. (1984). The Yeast. A taxonomic study Amsterdam: Elsevier Science. 50(5-6):795-805.

Morgan, N.K. and Choct, M. (2016). Cassava nutrient composition and nutritive value in poultry diets. Animal Nutri., 2(4):253-261.

Ngiki, Y. U., Igwebuike, J. U. and Moruppa, S. M. (2014). Utilization of cassava products for poultry feeding: a review. Int. J. Sci. Tech., 2(6):48-59.

Nwankwo, O. O., Anadu, E and Usoro, R. (1989). Cassava Fermenting Organisms. Mircen J.5:169-179.

Ofuya, C. O. and Nwajiuba, C. J. (1990). Microbial degradation and Utilization of Cassava Peel. W. J. Microbio. and Biotech. 6:144-148.

Ofuya, C.O. and Obilor, S. N. (1994). The effects of solid-state fermentation on the toxic components of cassava peel. Process Biochem. 29(1): 25-28.

Okhamafe, A. O., Igboechi, A. C. and Obaseki, T. O. (1991). Cellulose Extracted from groundnut shell and Rice Husk, Preliminary physicochemical characterization. Pharm. W. J.8 (4): 120-123.

Okolie, P. N and Ugochukwu, E. N. (1988). Changes in Activities of Cell Wall degrading enzymes during fermentation of Cassava (Manihot esculenta Crantz) with Citrobacter freundii J. Sci. Food and Agric.44:5161.

Omafuvbe, B. O., Falade, O. S., Osuntogun, B. A. and Adewusi, S.R.A. (2004). Chemical and biochemical changes in African locust bean (Parkia biglobosa) and melon (Citrullus vulgaris) seeds during fermentation to condiments. Pakis J. Nutri., 3:140-145.

Parada, J. L., Zapata, E., de Fabrizo, S. V. and Martinez, A. (1996). Microbiological and Technological Aspects of Cassava-starch fermentation. W. J. Microbio. and Biotech. 12:53-56.

Ray, R. (1995). Occurrence of the Linamarase producers in the microbial population of cassava environment. J. Environ. Biol. 16 (4): 319-323.

Rhode, B. and Hartman, G. (1980). Introducing Mycology by examples. Scherringaktiengesellshaft, Hamburg 139pp.

Sanni, L. O., Onadipe, O.O, Ilona, P., Mussagy, M.D., Abass, A. and Dixon, A.G.O. (2009). Successes and challenges of cassava enterprises in West Africa: a case study of Nigeria, Benin and Sierra Leone: International Institute of Tropical Agriculture (IITA)

USEPA, (2005). Municipal solid waste in the United States, facts and figures. USEPA archive document. pp165.

Zvauya, R. and Muzondo, M. I. (1995). Reduction of Cyanide Levels in Cassava during sequential sundrying and solid state fermentation. Intl. J. Food, Sci. and Nutri. 46 (1): 13-16. 